Michae Lachman

Uniwersytet Łódzki

\title{
Travelling Europe, Travelling through Crisis: Disintegrated Journeys in Dorota Masłowska’s A Couple of Poor, Polish-Speaking Romanians and Zinnie Harris's How To Hold Your Breath
}

1.

Many contemporary political and cultural debates circle around the concept of the precarious condition of life in a modern state. Fuelled by images of refugees and asylum seekers as well as those citizens of the European states who have lost employment and social stability, cultural discourses focus on the theme of political as well as ethical challenges to democracy and liberalism. Tested and contested, modern states are increasingly seen as illiberal and undemocratic, and in the eyes of many, precisely because of this devolution from legality to illegality, they seem to offer so much more in terms of safety and confidence. These political as well as ethical problems are debated in particular by playwrights and theatres which have the potential to tap into raw emotions of the public and follow their stories in unstable social environments. ${ }^{1}$ Often, these are stories from the margins, told by "stateless" individuals (Cf. Wilmer) touched by poverty and experiencing rejection, individuals whose narratives acquire exceptional diagnostic insightfulness. Dorota Masłowska's A Couple of Poor, Polish-Speaking Romanians (2006) and Zinnie Harris's How To Hold

1 Janelle Reinelt observes that theatre and performing arts are especially significant "in periods of crisis or flux," in which "theatre is especially well-suited to influence as well as to reflect the course of history by providing imaginative mimesis, transformative models, and observant critique" (366). 
Your Breath (2015) both assume a journeying perspective on Europe, creating characters who experience a number of exclusions and verbalise their discontent in a series of travels across the continent. The protagonists of these plays interrogate basic European values, as they voluntarily or involuntarily undertake journeys through provincial locations of what looks like the world falling apart.

The aim of this article is to penetrate the state of disintegration of social and cultural structures of the modern state represented in Harris's and Masłowska's plays. It is to analyse the disappearance of hope and belief in modern state institutions, the disrupted predictability of protocols, the collapse of routines of administrative operations. Both playwrights represent the European continent from the perspective of those who are spinning micro-narratives aimed against hegemonic European history. They incarnate the idea that having moved geographically from a settled place of location means losing the narrative control over the European story. They also manifestly show how quickly and effortlessly the European narrative disintegrates into chaotic senses, symbols or even individual syllables with the slightest anomaly of the system. Therefore, the article's objective is to investigate how Harris's and Masłowska's traveling protagonists interrogate the basic tenets of European culture today, how they test it and find it wanting.

Masłowska's A Couple of Poor, Polish-Speaking Romanians and Harris's How To Hold Your Breath depict Europe after the collapse of the Berlin Wall, after the accession of the Central-European countries, and after the expansion of the Union, which has in equal measure been perceived as strengthening its unity and as diluting its identity foundations. A significant evolution should perhaps be noted here in the selection of topics and approaches present in earlier dramatic texts. Such plays as David Edgar's Pentecost (1994), David Greig's Europe (1994) and Timberlake Wertenbaker's The Break of Day (1995), all written in the 1990 and composed as an immediate reaction to the formation of new Europe after the unification of Germany, tackled the issues of negative consequences caused by "migration, globalization, neo-capitalism and right-wing extremism" (Hauthal 29). By comparison, plays of the new millennium focus rather on the disintegration of the very idea of Europe and on showing individuals losing their firm footing in what used to constitute a stable structure of constitutional and institutional comfort. Both Malsowska and Harris present characters who have lost the sense of such cultural and institutional security. They are not only alternative and marginalized voices within an unstable system, but they experience lack of legitimation as their narrative perspectives fall out of mainstream discourses. The validity and power of one's voice is strictly dependent on the position of the subject within cultural and social spaces which rarely invite or 
accept challenge and subversion (Inchley 14). Although Masłowska's and Harris's protagonists are very eloquent talkers, imaginatively reinventing themselves under straining conditions, their cultural audibility (Inchley 1) nears zero.

Harris's female protagonists who undertake an almost impossible journey from England to Alexandria and Masłowska's strange couple traveling through desolate landscapes of central Poland not only indicate the collapse of institutional stability of the European nation states, but also produce voices which challenge Eurocentric discourse with the talk of the native, local and indigenous characters. Harris's Scottish perspective and Masłowska's almost surreal vision of the Central-European journey both expose the vernacular and the demotic, which as categories of cultural identity have been submerged by the dominant Eurocentric parlance. The weight and meaning of local voices is particularly significant for the identity of such countries as Ireland or Scotland pacing their way through early stages of post-devolution cultural politics. For example, the work of dramatists David Greig or Anthony Burke, among others, "articulates complex relationships between localised individual identities, globalisation and Scottish territorialisation" (Inchley 65). Harris's protagonists also explore exactly this connection between individual identity and global, trans-national citizenship. Individual identities which search for their "localization" are very much the core of Masłowska's story, in which two drug-wasted individuals assume false identities of poor Romanians. This semi-conscious trick gives them the power and possibility to explore the social and cultural environment from completely unorthodox perspectives, authoring the narrative of disintegration, loneliness and disappointment.

Displacement as a condition of epistemic challenge but also superiority remains a significant mode of thinking in various cultural environments. Irish and Scottish drama for one provide the talk and the act which refuse to reiterate the old European narrative whose domination and leadership had been founded on the colonial, imperial and ideological enterprise. Similarly, voices from Central and Eastern Europe, as well as from further afield, Russia, Middle or Far East, regularly showcased for instance in Royal Court Theatre's International Playwrights Season, add transcultural perspectives to the monolithic European narrative. For the majority of continental reviewers the immersion into the exoticism of such works offers a chance to undertake a veritable field trip into the unknown but eerily recognizable reality. In his review of Andrzej Stasiuk's Nine, Irvine Welsh, himself the author of the Scottish classic Trainspotting, stresses the universal value of the novel's "portrait of an uprooted and restless generation of Eastern Europeans," and ponders the condition of difference between Western and Eastern epic sensibilities: 
this book reminds us how much bland fiction we publish in the English-speaking world. Our cultural hegemony has its downside; our imagination is increasingly filtered through the marketing lens of escapist genre fiction, and our so-called literary novels often feel like rehashed classics brazenly trumpeted as original work. Our novels affirm rather than challenge our sense of ourselves in the world. (Welsh)

Such voices from the margins, vocalizing their critical polemic with the concept of modern Europe, reflect similar concerns within the academic and historical discourse. The expansion of the Union to the East enhanced the dynamics of monetary, political and cultural centralization of the continent placed under tighter scrutiny of what Timothy Garton Ash terms the "single grand narrative" of the "idealistic-ideological discourse of European unification" (Ash 52). Looking at Europe towards the end of the previous century (1998), Ash clearly perceived the difficulty of producing and imposing one narrative for all the member states which inhabited the continent "externally more ill-defined, internally more diverse, or historically more disorderly" (Ash 53). Already at the outset of the new millennium, one could clearly see the political challenges of such attempts subverted by the return of the identity politics and concepts of the nation.

Voicing his concern at the end of the 1990s, Ash also noted that:

European history provides no indication that the immensely diverse peoples of Europe-speaking such different languages, having such disparate histories, geographies, cultures, and economies are ready to merge peacefully and voluntarily into a single polity. (Ash 62)

These sentiments have been echoed by other historians of the continent who see in such dilemmas an indication of collapse. For Ivan Krastev, the common share of values had been outnumbered by disparities to the extent that "what once kept the union together no longer holds" (5). Krastev's vision of Europe is based, among other things, on the assumption that, along with the migration crisis, the continental societies suffer from an acute lack of representation (85). The crisis of liberal democracy can therefore be put down to a popular conviction that the "votes of individuals have no meaning or effect on European policy" (Krastev 110). This sense of having a voice with no power, of having a state with no representation in it, forms a significant portion of experience harboured by dramatic characters in Masłowska's and Harris's plays.

Especially the concept of Europe after the caesura of 1989 has been in the focus of dramatic works which interrogate what "new" evolutions are possible 
within the concepts of identity and legitimation policies. Here, for instance, Reinelt speaks of "performance as an intervention into the discourse of the New Europe" (384), the intervention that investigates "issues of displacement" and considers what "constitutes membership in any 'European community" in reference to "territoriality, historical memory, and social justice" (373). It is in this context that political drama of the Post-Wall period assumes a polemical stance against "Eurocentric historicism" (Hauthal 33). Allowing perspectives of reading it which had not had any power before, a number of playwrights could possibly aim at exploring the idea of Europe from new angles and subsequently open a path along which it "may be renewed from and for the margins" (Chakrabarty qtd. in Hauthal 34). Rehearsing such voices from the margins lies in the centre of dramatic achievement of Masłowska's and Harris's works. They attempt to show their protagonists on the move, not exclusively in the geographic sense, but primarily in reference to stable identities, belonging and stability of social environment. One could say that along with the mobile characters the continent of Europe also reveals a tendency of motion, evolving from order to disorder, from systemic regularity to institutional chaos, from continuity to disruption.

2.

Masłowska's A Couple of Poor, Polish-Speaking Romanians tells the story of Parcha and Dzina, a pair of travelling misfits who cannot shake the drug-induced haze caused by last night's excessive partying. They introduce themselves as "poor Romanians" who can speak Polish and hitch rides across the country, without paying particular attention whether their erratic journey takes them south or north. Yet, when the alcoholic intoxication evaporates, it turns out that the declared identities are merely party masks and their real purpose is a panicked return to Warsaw where they have left jobs and families. Masłowska, then, skilfully changes the mood of the play from frolic to desperate and shows the real hopelessness of life suspended between unfulfilled and wasted career prospects and damaged family relations. However, even when the false identities of the protagonists are finally exposed as such, Parcha and Dzina cannot fully recover their own true selves from under the enacted personages. Their artificial language and aggressive, xenophobic views stick to them for good, so that one cannot but assume them to be an authentic representation of the couple's real identities. Masłowska's particularly eloquent trick consists in showing that what the readers interpret as enacted poses of imbibed individuals, truly constitutes their worldviews which accurately describe the distorted, gloomy and trashy reality around them. 
It is primarily through these assumed identities-poor Romanians-that Masłowska's play reconnects with the European discourse most acutely. In an unjust hierarchy of colonial domination, both civilizational and cultural, there are a number of levels of degradation and contempt. ${ }^{2}$ While advanced economies of the core European nations would probably deem themselves superior to their eastern neighbours, among Central European states there is an equally unjust hierarchy of appreciation and achievement evidenced in prejudice. "The Romanians" brings about negative stereotypical associations which many Poles have towards their southern neighbours, and although Masłowska comically theatricalises this appellation, her protagonists do voice real prejudice commonly heard in Polish towns and villages. Parcha describes his relatives in Romania as people who write letters on tree bark ("with urine and feces. And Easter-egg dye") (Masłowska 8), and as those whose children cry for a Twix chocolate bar and dream about a "cardboard French-fry holder" as a precious souvenir (Masłowska 8 ). This ingrained prejudice, which indicates a peculiar kind of devolved colonialism, comes from the sentiment in which the colonised eagerly seeks to manage their own colonial discourse addressed to other, supposedly inferior nations. The colonial mimesis employed as a cohesive ideology to unify one's own culture constitutes a big portion of folk imagination in countries touched by imperial injustice. Masłowska turns this aspect of Polish marginalisation into a theatrical devise in which she can magnify the decomposition of reality.

The devastated and decomposed world through which Parcha and Dzina travel paints the picture of cultural periphery, of the margin of social and cultural structure which has lost any nurturing potential to mean and give meaning. Startling images of collapse are framed in the protagonists' journey as they hear stories about "bodies of run-over dogs and animals cast all over the highway" and about faded "Last year's ice-cream ads" (Masłowska 36). The marriage of cruelty and commerce, dead animals flagged with commercial symbols of capitalism, aptly indicates the deadly kitsch of trashy existence somewhere on the margins of what the play seems to depict as a crumbling European project. The characters are irreparably damaged by the cheap disposability of their existence, which merely provides raw material for commercial and consumer industry. ${ }^{3}$ Parcha turns out to be a soap opera actor, starring a parish priest in a popular TV series, whose popularity in provincial villages has eaten up whatever remains of his true, non-filmic identity. All of the encounters that the

2 For a comprehensive study of Masłowska's writing in the context of Polish colonial studies see: Snochowska-Gonzales.

3 For more contexts on Masłowska's anticommercial and anticapitalistic views see: Lease. 
couple have on their way home bring them into contact with equally wasted individuals, devastated by fear, destroyed with drink. Finally, the protagonists end up in a remote forest lodge inhabited by an old man collecting trash. They fall asleep among destroyed home appliances and broken tools. The sense of life on a huge garbage dump in the middle of European nowhere magnifies the voice of dissent that speaks through the two protagonists in Masłowska's play. Clearly, the scene also reflects on a long history of industrialisation, highlighting its destructive legacy of both social and ecological dimensions.

The theme of the journey through European province not only helps to energise significant encounters with the local people, but it also adds to the sense of futility of progress and hope. As the drama unfolds, it is revealed that Parcha needs to reach Warsaw at a specified time to start filming a new episode of the series, and Dzina must collect her child from kindergarten where she left it on the way to the party. The futility of any attempts to travel successfully, the idea that they will not be able to arrive at their destinations on time, combined with the technical impossibility to communicate with the use of phone manifestly indicate the hopelessness of planning. Parcha and Dzina move through zones where phone connection cannot be obtained, symbolically drawing a map of European province disconnected from the circuit of civilizational betterment. The play ends with a surreal vision in which Parcha imagines a cargo ship named Ibuprom $^{4}$ on which they might sail away, was it not for the fact that Dzina has just committed suicide by hanging herself in the toilet. This oneiric vision, which makes it impossible to determine how the play actually ends, returns to the issues of poverty, social rejection and intercultural contact tinged with colonial injustice, proving the play to be among others a scrap book of quotes, a string of cultural clichés and a collection of recycled material.

3.

There are a number of striking parallels between Masłowska's work and Zinnie Harris's How to Hold Your Breath. The journey through provincial Europe, the impossibility of reaching their destination, the image of the continent descending into ruin form the characters' sense of apocalypse which exists also in Parcha's and Dzina's ironic denial of responsibility and rational thinking. Harris plunges her two female protagonists-Dana and Jasmine-into reality decomposed by surreal logic of even greater degree than Masłowska's. They face a total collapse

4 "Prom" being a Polish word for ferry, which offers one of many examples of Masłowska's linguistic creativity. 
of the European society when banks suspend their operations, mobile phones remain silent, and their journey to an enigmatic job interview in Alexandria turns into a Biblical exodus from the old continent to the South. This intended reversal of the usual route of migration invites the question of what would happen if it were the native Europeans asking for help and shelter the citizens of the Arabic countries. This shocking switch of perspective also shifts moral and ethical responsibilities and exposes the misguided belief in stability and power that the European continent harbours against better judgement. Dana and Jasmine end up on an overcrowded boat, sailing towards more welcoming shores of southern Mediterranean. They drown on the way but Dana is miraculously brought back to life by a magical figure of a UN officer who has a whim of letting her go to the desired job interview having first dressed her in elegant clothes scavenged from the dead bodies of her fellow refugees.

Harris's dramatic world melts into fantasy from the very beginning only to expose almost Freudian fears that plague the unstable consciousness of modern Europeans. More importantly however, the play operates with known clichés of stability, safety, complacency and control that constitute the foundation of European sense of superiority. Even at the time of complete collapse, Harris's protagonists somewhat naively persist in narrating stories of hope, incarnating the already much decomposed myth of progress, modernisation and corporate ethics that the European ethos of industrialism had been founded upon. They maintain an unshaken conviction that the traditional reliability of European institutions and ideals will play in their favour. Harris exposes such fantasies as the tragically misguided legacy of education and teaching that each European acquires through various forms of easily available learning. Ironically, the two women are assisted by a librarian whose sole purpose is to offer them cheap guidebooks containing instructions to help yourself in difficult situations. The parody of European academic tradition, philosophy and learning testified to by such titles as A Guide to Alsace Wine, Overcoming Insomnia, What to Say on a First Date, or Topiary for Beginners exposes the weakness of the current European project in its intellectual and philosophical dimensions. Ultimately, then, Harris dramatizes the tragic fate that the European societies face as a result of eroded foundational narrative, the inability to produce an adequate discourse, the collapse of the superior European story.

The sense that Europe with its ancient university tradition and impressive propaganda technology lacks the ability to authoritatively argue its identity is communicated even more pointedly when Dana rehearses her job interview speech against the background of the collapsing world. The two women are unable to use their credit cards to pay for train tickets, they can't find a working 
hotel, they have problems seeking medical assistance and cannot find any means of transport to reach Alexandria. On top of that, they suffer maltreatment and sexual assault, desperately trying to procure at least minimal income to further their journey. Yet, what Dana has prepared for her would-be employer speaks volumes about the mismatch of theory and practice, about the gap between expert assessment of reality and the actual situation on the ground. She, therefore, produces a similarly bizarre jargon as the comically inadequate titles of the guidebooks circulated by the librarian:

Now the usual situation is that in the inspector's mind the customer quickly changes from a would-be positive collaborator on our shared enterprise of paying and experiencing a pleasant-as-advertised journey to some kind of criminal. (Harris 89 )

With the title of her presentation being "How to still be civil when something goes wrong," it simply exposes the fact that the European experts, authorities, academics and the media have lost control over the facts which require a drastically different narrative. This epistemological collapse of knowledge, the surprised and surprising lack of competence in offering a legitimate diagnosis of the situation indicates a universal lack of authority on the side of the European intellectual tradition. The narrative of the margins is vocally expressed by images of the systemic meltdown which renders Harris's protagonists as refugees from their own continent or by the bleak fantasy into which Masłowska's characters descend only to expose an even greater disintegration of their own identity, hope and sense of purpose. Harris's play suggests that these issues have been systematically overlooked by leading European think tanks and research groups.

4 .

The protagonists of the two plays can therefore be seen as specifically constructed identities, bodies and subjects exposed to a variety of influence. Or, rather, shall we say, these are people left alone, as if stranded without instruction, neglected by the dominating narrative of the state, of the European project and its institutions. On this hinges the ironic and tragic fate of Masłowska's and Harris's visions, that is the concept of an individual who has been conditioned to function solely within the narrow limits of the underclass. The comfort of the subaltern, the desire to have your paths paved for you, straight and predictable, make the detours of the dramatic protagonists so tragic and painful. Their desperate attempts to connect, via disrupted phone lines, train connections or 
money transfers, indicates where the future state of Europe might lie; judging by what the two playwrights present, it definitely is not in the revolution of the subaltern groups, passive or active as Antonio Gramsci would have it, not in the speaking subjects of Spivak's "Can the subaltern speak," certainly not in mimicry rebelling against the colonizing culture which Homi Bhabha described (cf. Bhabha). The modern European citizen is left utterly hopeless without a selected protocol for action, unable to act efficiently despite their best efforts.

These dramatic subjects incarnate perfectly, yet with a parodic reversal, a number of current discourses from labour relations to pregnancy and motherhood. It is curious to see that both Harris's protagonist, Dana, and Masłowska's, Parcha, undertake their journey to secure a job, to follow the regime of economy and labour. The mysterious trip to Alexandria through the European continent which has suddenly disintegrated into chaos bears the mark of a desperate attempt to keep up the mirage of the effluent, middle class life that the characters of How to Hold Your Breath are used to. Similarly, Masłowska's work is pervaded with images of poverty mixed with dreams of unattainable wealth, and the desire to possess it. Thus Parcha, who risks losing his job as an actor, chases every chance to reach his destination, spuming stories of affluence against the looming danger of being left with no means to live. All of the characters in both plays are thoroughly versed in corporate jargon or business speech, which not only defines the normative remit of expectation but primarily turns their actions into the mimicry of success and fulfilment; this is outwardly mocked by images of Europe in total collapse or in utter ruin. ${ }^{5}$

Furthermore, both Masłowska and Harris place maternity and child birth in the centre of their stories. Here again, they dramatise the norm that no longer exists. Not only are the two pregnancies (Dana's sister's and Dzina's) unplanned and coincidental, they terminate either in miscarriage or in a state of fantasy, as Masłowska never specifies if her heroine's pregnancy is actual or acted. Child birth cannot happen according to the usual routine, as the rest of the world has gone out of line with logic. Pregnancy, which symbolizes the dream of stability and continuity, tests and examines the condition of contemporary society for its readiness to offer support, help, and institutional reliability. The characters are seeking traditional order in the world which no longer has it; they have

5 I use the concept of "mimicry" following Homi Bhabha's theory in which it is a model of existing under colonial domination. The colonized subject is supposed to be "almost the same, but not quite" (Bhabha126). In Bhabha's view, the colonial imitation can never be perfect, it inevitably entails some "excess" or "difference," and thus lies close to mockery (cf. Ashcroft, Griffiths, Tiffin). 
internalized the norm and the routine which can be delivered no more. Love turns into a toxic indication of the corruption and degradation of the whole system, when in Harris's play casual sex leaves a nasty mark on Dana's skin, which gradually invades her entire body. Likewise, in Masłowska's play the theme of Dzina's abandoned child, left behind in kindergarten and stranded there for far too long, increases the desperation of the characters seeking ways to restore their usual routines. Both plays, then, represent individuals who actively rely on traditional, patriarchal discipline and order, who have no desire to speak outside of the accepted norm even if it turns out to be colonial, racist and abusive towards minorities and other cultures. Quite to the contrary, they would eagerly reinstate this order and rescue it from collapse, if it was not for their dramatically limited capabilities to stop the inevitable ruin of the system.

Masłowska and Harris represent the termination of the central power, of the dominating discourse, of the colonial rule or the imperial, economic order. The metropolis has suddenly gone silent and inactive, leaving its subjects with protocols which no one can practice or supervise any more. Therefore, Parcha and Dzina dream about the mystical "Warsaw" whose centrality and power are supposed to restore order. Yet, the fact that this destination remains unreachable means that no redemption from chaos, dirt and poverty is ever possible. Harris's protagonists, in turn, stubbornly harbour hope and feel no fear. Why? As one of them says "because we live in Europe, because nothing really bad happens" (Harris 102). Thus, they continue to live a myth of the continent protected against any instability characteristic for the stereotypical third world country. The impossibility of repeating the usual pattern, of holding onto the mimetic identity in which the characters could reproduce their known self, remains the key dilemma of the two plays. The tragedy of the characters boils down to the fact that they are unable to use the knowledge of reality which they thought constituted their permanent premise for acting and thinking.

The system cannot be replicated any more, and the void that ensues requires from the protagonists to narrate their own stories, to produce their own legitimating discourse, which naturally proves impossible. In both cases the image of the characters' struggles turns into semi-parodic representation of crisis, exactly as in Bhabha's vision: he argues that between mimicry and mockery there is the space "where the reforming, civilizing mission is threatened by the displacing gaze of its disciplinary double" (Bhabha 127). Harris's and Masłowska's heroines incarnate the perfect doubles of the system; they both maintain it and simultaneously threaten it, they replicate it, yet never reach a perfect imitation, always desire it incorrectly, "rupturing" the official discourse (Bhabha 127). Possibly, both plays can also be seen as images of the post-industrial, globally capitalistic 
cultures in which precisely the "disrupted" condition of life remains the only option available. In a sense, the nomadic, discontinued and geographically dispersed order of capitalist economy helps it survive and reproduce itself at the brink of constant catastrophe.

Under this economic and cultural domination, which sets the standards of excellence and draws the norms of achievement, the dramatic protagonists can be seen as colonized. It is worth posing the question asked by Spivak in a different, strictly colonial context, namely who has "the permission to narrate" under such circumstances. What follows from this inquiry is naturally the issue of sovereignty of what Spivak terms "the subject of the West, or the West as Subject" (66) as opposed to the disempowered subjects or the "Other of Europe" (75). Interestingly, all of the characters created by Masłowska and Harris in their plays incarnate the concept of the "Other of Europe," forming the disempowered margins both in epistemic and moral senses. These subjects, unlike the ones analysed by Spivak, are incapable of "insurgency" (82), as they are unable to utter their needs or desires outside of the normative and imposed expectation. They produce the voice of the rejected, the displaced, the non-citizens of the Western world. The voice belongs to those who have permanently or temporarily been excluded from the benefit of service by modern democratic institutions. The micro-stories, private experience, individual feelings of Masłowska's and Harris's characters betray a striking disparity between the language of experts, of official analysis, of European positivism and the real level of fear, despair and instability of those individuals who experience in Spivak's words the "epistemic violence" (76) that defines every colonial subject.

5.

Moving the action to the outskirts of Europe, as in Masłowska's Poland, or changing Europe into an oneiric vision of collapse as in Harris's drama shifts the perspective from which the dramatic characters speak, giving them the possibility to form opinions both from the inside of the system as well as from an alienating distance to it. The "partial presence" of the colonial subject, which Bhabha speaks about, also defines the kind of mimicry represented by Masłowska's and Harris's protagonists whose imitation of the system's values and rules is "incomplete" and often "virtual" (Bhabha 127). In other words, they are and simultaneously they are not typical Europeans, they strive to embrace the dominant discourse of economic and personal success but always manage it only insufficiently, with an ironic difference, appropriating it partly or erroneously. In other plays, Harris's dramatic style is tailored to focus on cultural 
antagonisms between ethnicities (Boll 26), reflecting these tensions within and between small communities (Boll 27). This is the case with her war trilogy (Midwinter, Solstice, Fall), which is set in an post-conflict landscape touched with devastation. How to Hold Your Breath goes even further into dislocating the standard realism of political drama. Harris shows characters epitomizing universal values of safety, loyalty, desire or greed and, as one reviewer observed, her drama resembles "medieval plays," making the work feel "like a modern morality play" (Billington). The "mythical landscape" which Harris (Taylor 2005) employs in her drama coupled with the set design filled with the "detritus of a disintegrating civilization" (Billington) produce voices which both belong and do not belong to the European culture. They simultaneously simulate and dissimulate its core values, they uphold them and betray them at the same time.

In the case of Masłowska's work, the discourse of strangeness or even exoticism is evident in every review. A Couple of Poor Polish-Speaking Romanians is seen as a "picaresque dream," having "surreal style" and resembling a "wacky road movie" (Fisher). Her protagonists are called "hitchhikers from hell," and according to Paul Taylor, the play itself belongs to the genre of the "twisted fable" (2008). Roman Pawłowski, who was reviewing the play for Gazeta Wyborcza, saw it as a theatrical manifestation of a universal problem of social exclusion. In his opinion, Masłowska's characters willingly go down the social ladder to experience something extraordinary and exotic. When the return to reality proves too difficult, the play begins to speak realistically about capitalism and poverty of such post-Communist countries as Poland-a country which experiences "its own inferiority" on a daily basis. Pawłowski sums up his review by saying that some things are seen more clearly when viewed from the position of an underdog (Pawłowski). Therefore, Masłowska’s play, even more blatantly than Harris's, showcases the internal workings of decomposition of the continental idea of progress, of social justice and a number of discourses constitutive for the dominant strand within the continent's identity. The Chicago production of A Couple of Poor Polish-Speaking Romanians was announced as a "scathing critique of the relationship between class stratification and national identity" (Trap Door Theatre). The fact that Masłowska takes up these issues in a comic, yet harsh critical representation determines her protagonists' uneasy attitude to their own sense of belonging filled with metropolitan ambitions and provincial degradation. What the reviewer of the Soho Theatre production notes as "avant-garde, dirty realism from Eastern Europe" (Fisher) voices exactly this misspelled identity of the margin, the area whose dreams of being European are half baked and not entirely honest, and thus almost successful, but not really so. Many recognizable artistic schools prove useful to describe the foreign looking 
aesthetics of her writing, which western or American audiences may find bizarre. "Breathtaking expressionist theatre" is what the reviewer of the Chicago Trap Door Theatre sees in the play (Westin), while the critic analyzing the Newton Theatre production in Sydney observes that Masłowska's style contains "starkly black humour" (Newton Theatre).

Pitching the tone between what is familiar and foreign, the two playwrights stage a set of alternative voices. In this sense the plays challenge the Eurocentric vision. Together with political plays from the 1990 (e.g. David Greig's Europe), they provide discourses through which "Europe is being increasingly provincialized from 'within"' (Hauthal 39). The concept of the margin of culture or identity, of the European "other" that resides right in the centre of the continent drives the dynamic of modern drama. It is the expression of the precarious condition of the political system slowly losing control over its operation and narrative, it is a concept of male and female character trying to find a way out.

\section{| Works Cited}

Ash, Timothy, Garton. "Europe's Endangered Liberal Order." Foreign Affairs 77.2 (1998): 51-65.

Ashcroft, Bill, Gareth Griffiths, and Helen Tiffin. "Mimicry." Post-Colonial

Studies. Key Concepts. London and New York: Routledge, 2007. 124-127.

Bhabha, Homi. "Of Mimicry and Man: The Ambivalence of Colonial Discourse."

Discipleship: A Special Issue on Psychoanalysis 28 (1984): 125-133.

Billington, Michael. "How to Hold Your Breath review." The Guardian 11 Feb.

2015, https://tinyurl.com/5xa5cp43. Accessed 10 May 2021.

Bool, Julia. The New War Plays. From Kane to Harris. Basingstoke: Palgrave

Macmillan, 2013.

Fisher, Philip. “A Couple of Poor, Polish-Speaking Romanians.” British Theatre

Guide 2008, https://www.britishtheatreguide.info/reviews/poorpolish-rev.

Accessed 10 May 20201.

Harris, Zinnie, How to Hold Your Breath. London: Faber and Faber, pdf.

Hauthal, Janine. "Provincializing' Post-Wall Europe: Transcultural Critique of

Eurocentric Historicism in Pentecost, Europe and The Break of Day." Journal

of Contemporary Drama in English 3.1 (2015): 28-46.

Inchley, Maggie. Voice and New Writing, 1997-2007: Articulating the Demos.

Basingstoke: Palgrave Macmillan, 2015.

Krastev, Ivan. After Europe. Philadelphia: University of Pennsylvania Press, 2017. 
Lease, Bryce. "Paweł Demirski and Dorota Masłowska: Painful Pasts, transformative presents." Contemporary European Playwirghs. Eds. Maria M. Delgado, Bryce Lease and Dan Rebellato. London and New York: Routledge, 2020. 185-203.

Masłowska, Dorota, A Couple of Poor, Polish-Speaking Romanians. Trans. Benjamin Paloff, pdf.

Newton Theatre. "A Couple Of Poor, Polish-Speaking Romanians." Crikey 04 Aug. 2010, https://tinyurl.com/4semxthu. Accessed 10 May 2021.

Pawłowski, Roman. “Teatralna brama na wschód.” Gazeta Wyborcza 30 Nov. 2007, https://wyborcza.pl/1,75410,4719902.html. Accessed 10 May 2021.

Reinelt, Janelle G. "Performing Europe: Identity Formation for a 'New' Europe.” Theatre Journal 53. 3 (2001): 365-387.

Snochowska-Gonzales, Claudia. Wolność i pisanie. Dorota Masłowska i Andrzej Stasiuk $w$ postkolonialnej Polsce. Warszawa: Oficyna Naukowa, 2017.

Spivak, Gayatri, Chakravorty. "Can the Subaltern Speak?" Marxism and the Interpretation of Culture. Eds. C. Nelson and L. Grossberg. Basingstoke: Macmillan, 1988. 271-313.

Taylor, Paul. "Midwinter." The Independent 15 March 2005, https://tinyurl.com/zc6jdrd3. Accessed 10 May 2021.

---. “A Couple of Poor, Polish-Speaking Romanians.” The Independent 11 March 2008, https://tinyurl.com/ccv4d728. Accessed 10 May 2021.

Trap Door Theatre. A Couple of Poor, Polish-Speaking Romanians. 2009, https://trapdoortheatre.com/performance-history/polish-romanians/. Accessed 10 May 2021.

Welsh, Irvine. "Warsaw Underground." The New York Times 10 June 2007, https://www.nytimes.com/2007/o6/10/books/review/Welsh-t.html. Accessed 10 May 2021.

Westin, Monica. "Review: A Couple of Poor, Polish-Speaking Romanians/Trap Door Theatre." Newcity Stage 25 May 2009, https://tinyurl.com/e78n5udc. Accessed 10 May 2021.

Wilmer, Stephen, E. Performing Statelessness in Europe. Cham: Palgrave Macmillan, 2018. 


\section{| Abstract}

\section{Michal Lachman}

Travelling Europe, Travelling through Crisis: Disintegrated Journeys in Dorota Masłowska's A Couple of Poor, Polish-Speaking Romanians and Zinnie Harris's How To Hold Your Breath

The article reflects on the issues of European social, political and ethical disintegration by looking at two plays which represent both geographic and mental migration of European citizens. Zinnie Harris's play dramatizes a journey by an energetic businesswoman from the state of seeming success to the condition of collapse of the entire continent. Masłowska's drama tells the story of a couple who have lost their geographic but also existential bearings after a prolonged bout of drug abuse and partying. The article aims at presenting the European continent as a space of alienated social and personal experience, as a community of people in permanent exile from both the private space and the public ideologies. The two plays offer a reflection on the condition of pre-Brexit Europe with the power of capturing representative lives of those individuals who have lost the sense of the common cause.

Keywords: Dorota Masłowska; Zinnie Harris; contemporary drama; crisis; colonialism

\section{| Abstrakt}

\section{Michat LaChman}

Przemierzając Europę, przemierzając kryzys: trudne podróże w dramacie Dwoje biednych Rumunów mówiących po polsku Doroty Masłowskiej i w How to Hold Your Breath Zinnie Harris

Artykuł ukazuje społeczną, polityczną i etyczną dezintegrację koncepcji wspólnej Europy na przykładzie dwóch dramatów opowiadających historie geograficznej i tożsamościowej migracji Europejczyków. Sztuka Zinnie Harris przedstawia podróż z Wielkiej Brytanii do Aleksandrii, której towarzyszy finansowy i instytucjonalny upadek europejskich struktur państwowych. W dramacie Masłowskiej ukazana zostaje historia dwóch podróżujących osób, które straciły zarówno tożsamość, jak i kontrolę nad własnym losem i kierunkiem podróży. W obu utworach Europa jawi się jako miejsce alienacji, jako wspólnota poszukująca tożsamości i doświadczająca wykluczenia. Autorki opowiadają o kryzysie tożsamości, który widoczny był 
w okresie przed brexitem, a który obecnie stanowi główne wyzwanie kontynentu poszukującego nowej idei wspólnotowej.

Słowa kluczowe: Dorota Masłowska; Zinnie Harris; dramat współczesny; kryzys; kolonializm

\section{| About the Author}

Prof. Michał Lachman is a Lecturer in English and Irish Drama at the Department of English Drama, Theatre and Film, University of Lodz, Poland. His research interests include the history of the twentieth-century British and Irish drama, literary theory and translation. He has published on Brian Friel, Martin McDonagh, Sarah Kane, Mark Ravenhill and Howard Barker. He has translated Christina Reid's Belle of the Belfast City, Billy Roche's A Handful of Stars, Frank McGuinness's Observe the Sons of Ulster Marching Towards the Somme and Innocence into Polish. In 2018, he published Performing Character in Modern Irish Drama: Between Art and Society (Palgrave). E-mail: michal.lachman@uni.lodz.pl

ORCID: 0000-0002-6273-825X 